Article

\title{
Impact of Linseed Variety, Location and Production Year on Seed Yield, Oil Content and Its Composition
}

\author{
Barbara Čeh ${ }^{1, *}$, Saša Štraus ${ }^{2}$, Aleš Hladnik ${ }^{3}{ }^{[}$and Anita Kušar ${ }^{4}$ (D) \\ 1 Slovenian Institute of Hop Research and Brewing, 3310 Žalec, Slovenia \\ 2 Pan-nutri, d. o. o., 9000 Murska Sobota, Slovenia; sasa.straus@pan-nutri.si \\ 3 Faculty of Natural Sciences and Engineering, University of Ljubljana, 1000 Ljubljana, Slovenia; \\ ales.hladnik@ntf.uni-lj.si \\ 4 Nutrition Institute, 1000 Ljubljana, Slovenia; anita.kusar@nutris.org \\ * Correspondence: barbara.ceh@ihps.si; Tel.: +386-3-71-21-612
}

Received: 5 October 2020; Accepted: 9 November 2020; Published: 12 November 2020

\begin{abstract}
Linseed (Linum usitatissimum L.) is a traditional oilseed crop in Europe that represents a valuable alternative for cropping systems because of the high quality of the seed oil, which is being increasingly appreciated by consumers, food, cosmetic and ecomaterials industries. The aim of this study was to evaluate the influence of linseed variety and year of production in relation to weather conditions on seed yields, oil content and its quality, with a focus on human nutrition value, through a field study carried at four different locations in Slovenia. Six early French linseed varieties were studied: Recital, Niagara, Princess, Altess, Comtess and Duchess. The seed yield was significantly affected by the year of production (413 kg/ha higher in 2012 compared to 2013), the location and the variety. The environmental factors that negatively affect seed yield are high temperatures in summer, water shortage and wet and cold soil in spring. The highest seed yield was reached at mid-heavy soil (1907 kg/ha) in the region with higher precipitation amount, while the lowest on light soil (1052 kg/ha) in the region with a lower precipitation amount. Comtess and Altess varieties, followed by Duchess, would be recommendable for Slovenian environmental conditions. Comtess variety gave the significantly highest oil yield. There were no significant differences in oil content between varieties. The content of $\alpha$-linolenic acid was highly related to genetic and environmental factors. The ratio of omega- 3 and omega- 6 fatty acids was recognized as favorable for human health for all studied varieties. The content of $\alpha$-linolenic acid in seeds from the Altess, Comtess and Duchess varieties exceeded the averages of 2012 and 2013, at 50.3\% and 51.6\%, respectively. The omega-3:omega-6 ratio ranged from 3:1 to 4:1 among varieties.
\end{abstract}

Keywords: Linum usitatissimum L.; linseed; seed yield; nutrition quality; oil; field production; growth conditions

\section{Introduction}

Linseed (Linum usitatissimum L.) is a traditional oilseed crop that represents a valuable alternative for cropping systems due to its adaptability to poor soils and its high economic value relative to the high quality of the seed oil, which is being increasingly appreciated by consumers, the food industry and the cosmetics and ecomaterials industries [1]. Several findings all over Europe suggest that the species has played an important role in nutrition and handcraft since the Neolithic period; presumably, the domestication of Linum bienne started in central Europe to obtain oil and fibers; cultivation in central Europe peaked during the eighteenth century due to the fabrication of linen textiles [2]. Although linseed is a plant species with a high adapting capacity to unfavorable environmental conditions, which enables expansion of the cultivated land area under various agroecological conditions, the cultivated 
area of linseed is limited (nearly 2,800,000 ha in the world in 2017 and nearly 3,300,000 ha in 2018) with an average yield of about 1 ton. In Europe, in the last five years, the area is between 800,000 ha and 900,000 ha, with a yield of $0.8 \mathrm{t} / \mathrm{ha}$ to $1.1 \mathrm{t} / \mathrm{ha}$ [3]. Nevertheless, for example, in Germany, varietal range in seed yield has been observed from 2.35 to $2.6 \mathrm{t} / \mathrm{ha}$ in conventional farming, and from 1.4 to $1.9 \mathrm{t} / \mathrm{ha}$ in Switzerland in organic farming [2].

Oil content and its fatty acids composition are the main parameters for linseed when evaluating nutrition quality. Linseed seed yield in European countries is highly variable [4]: linseed thrives best in regions with temperate climates with moderate warmth, high humidity and well-drained medium-heavy soils [5]. In order to reach high linseed oil yield and quality, it is necessary to understand the factors of influence. Cool climates usually result in high oil and low protein content in seed [6]. Seed quality and quantity are known to be influenced by genotype, growing season, geographic location and agronomic practices [7]. Weather conditions (temperature and rainfall regime) could also have an important effect on the yield and quality of produced seeds [8]. Environmental conditions influence crop growth and development, which are the most vital factors in reducing crop productivity [9]. Cool climatic conditions in temperate regions lead to a high share of omega-3 fatty acids. Continental temperate climate influences a higher content of polyunsaturated fatty acid (ALA) and lower content of oleic acid (monounsaturated fatty acid) in comparison to crops from Mediterranean and subtropical regions [2]. Oil content is higher when linseed grows at lower temperatures. It has a rather high demand for water -400 to $450 \mathrm{~mm}$ in the growth period (140 days). The increase of plant-available water in the soil from $40 \%$ to $80 \%$ increased the seed yield per plant by a factor of 1.89 , while oil content rose by about $2.5 \%$ [2].

Seeds are rich in omega-3 fatty acids (FA) and lignans, are a source of high-quality protein and soluble fiber and also have considerable potential as a source of phenolic compounds [6]. The oil content of linseed seed ranges between $35 \%$ and $45 \%(w / w)$, although even higher values have been reported [10]. Generally, linseed seed oil contains approximately $9-11 \%$ saturated (5-6\% palmitic acid and $4-5 \%$ stearic acid) and 75-90\% unsaturated FA (50-55\% $\alpha$-linolenic acid, $15-20 \%$ oleic acid) [11]. Compared to other oilseed crops, linseed oil is the richest source of omega- 3 and $\alpha$-linolenic acid (ALA) [12]. Linseed seed oil also has a beneficial ratio (n-6:n-3) of fatty acid (FA) of approximately 0.3:1 [13,14]. Genetic and environmental factors such as soil and climate can influence linseed seed yield, oil content and the FA composition of seed oil and seed press cake $[6,15,16]$. The linseed variety influences the quality of the seeds, and respective varieties must be chosen to improve the linseed product quality [2]. Assessment of linseed varieties in different environmental conditions becomes essential before planning an appropriate cultivation strategy [17].

The aim of this study was to evaluate the influence of linseed variety, year of production in tight relation to weather conditions on seed yields, oil content and its quality, with a focus on human nutrition value, through a field study carried on four different locations in Slovenia.

\section{Materials and Methods}

\subsection{Description of Site and Weather Conditions}

Varietal field trials were conducted in Slovenia at four different locations-two in the Savinja Valley (Žalec) and two in East Slovenia (Murska Sobota and Rakičan)—in 2012 and 2013. Location characteristics are presented in Table 1.

The spring of 2012 was warm and dry, with scarce rainfall lasting from autumn 2011 to spring of 2012. Winter and spring of 2013 were very wet: the spring was cold, and the soil remained wet for a long time. The summer of 2013 was dominated by a shortage of rainfall, accompanied by very high temperatures (up to $40{ }^{\circ} \mathrm{C}$ ) (Figures 1 and 2). During the growing season (from the beginning of April to mid-August), there was $569 \mathrm{~mm}$ of rainfall in 2012 and $362 \mathrm{~mm}$ in 2013 in the Savinja Valley and, in East Slovenia, $388 \mathrm{~mm}$ in 2012 and $258 \mathrm{~mm}$ in 2013. Compared to the Savinja Valley, the East 
Slovenia locations received considerably less rainfall during the growing seasons in 2012 (a difference of $181 \mathrm{~mm}$ ) and $2013(104 \mathrm{~mm})$. The mean temperature and its fluctuations were similar [18].

Table 1. Locations characteristics and some agrotechnical measures.

\begin{tabular}{|c|c|c|c|c|}
\hline \multirow[b]{2}{*}{ Abbreviation } & \multicolumn{2}{|c|}{ Savinja Valley } & \multicolumn{2}{|c|}{ East Slovenia } \\
\hline & SV1 & SV2 & PM1 & PM2 \\
\hline & $\begin{array}{l}\text { Savinja Valley—heavy } \\
\text { soil }\end{array}$ & $\begin{array}{l}\text { Savinja } \\
\text { Valley-medium-heavy } \\
\text { soil }\end{array}$ & $\begin{array}{l}\text { East Slovenia—heavy } \\
\text { soil }\end{array}$ & $\begin{array}{l}\text { East Slovenia- light } \\
\text { soil }\end{array}$ \\
\hline Coordinates & $\begin{array}{l}\text { GKY: 512,835; GKX: } \\
12,2796\end{array}$ & $\begin{array}{l}\text { GKY: 512,871; GKX: } \\
122,793\end{array}$ & $\begin{array}{l}\text { Murska } \\
\text { Sobota-593,195, } \\
\text { GKX: } 168,428\end{array}$ & $\begin{array}{l}\text { Rakičan-GKY: } \\
\text { 589,889, GKX: } \\
166,228\end{array}$ \\
\hline Soil type & $\begin{array}{l}\text { Alluvial/riparian, } \\
\text { brown, } \\
\text { medium-deep, } \\
\text { texture class clay } \\
\text { loam. In deeper } \\
\text { horizons, signs of } \\
\text { water retention were } \\
\text { noticed. }\end{array}$ & $\begin{array}{l}\text { Medium-deep eutric } \\
\text { brown soil on a } \\
\text { sandy-gravel basis. } \\
\text { Upper horizon was } \\
\text { loam-sandy clay } \\
\text { loam class } \\
\text { (medium-heavy soil). }\end{array}$ & $\begin{array}{l}\text { District brown soil, } \\
\text { silty clay loam }\end{array}$ & $\begin{array}{l}\text { District brown soil, } \\
\text { sandy-gravel }\end{array}$ \\
\hline $\mathrm{pH}$ & 6.8 & 6.6 & 5.6 & 6.2 \\
\hline $\begin{array}{l}\text { Plant-available amounts } \\
\text { of phosphorus }\left(\mathrm{P}_{2} \mathrm{O}_{5}\right)\end{array}$ & $\begin{array}{l}30.1 \mathrm{mg} / 100 \mathrm{~g} \text { of soil } \\
\text { (excessive supply) }\end{array}$ & $\begin{array}{l}19.9 \mathrm{mg} / 100 \mathrm{~g} \text { of soil } \\
\text { (oversupplied) }\end{array}$ & $\begin{array}{l}14.6 \mathrm{mg} / 100 \mathrm{~g} \text { of soil } \\
\text { (well supplied) }\end{array}$ & $\begin{array}{l}51.5 \mathrm{mg} / 100 \mathrm{~g} \text { of soil } \\
\text { (extremely supplied) }\end{array}$ \\
\hline $\begin{array}{l}\text { Plant-available amounts } \\
\text { of potassium }\left(\mathrm{K}_{2} \mathrm{O}\right)\end{array}$ & $\begin{array}{l}13.7 \mathrm{mg} / 100 \mathrm{~g} \text { of soil } \\
\text { (semi-well supplied) }\end{array}$ & $\begin{array}{l}34.5 \mathrm{mg} / 100 \mathrm{~g} \text { of soil } \\
\text { (oversupplied) }\end{array}$ & $\begin{array}{l}17.6 \mathrm{mg} / 100 \mathrm{~g} \text { of soil } \\
\text { (semi-well supplied) }\end{array}$ & $\begin{array}{l}23.6 \mathrm{mg} / 100 \mathrm{~g} \text { of soil } \\
\text { (well supplied) }\end{array}$ \\
\hline $\begin{array}{l}\text { Soil organic matter } \\
\text { content }\end{array}$ & $2.7 \%$ & $2.5 \%$ & $3.4 \%$ & $1.9 \%$ \\
\hline $\begin{array}{l}\text { Nmin content of the soil } \\
\text { before blossoming in } \\
2013\end{array}$ & $<15 \mathrm{~kg} / \mathrm{ha}$ & $<15 \mathrm{~kg} / \mathrm{ha}$ & $30 \mathrm{~kg} / \mathrm{ha}$ & $30 \mathrm{~kg} / \mathrm{ha}$ \\
\hline $\begin{array}{l}\text { Nmin content of the soil } \\
\text { after harvest in } 2013\end{array}$ & $44 \mathrm{~kg} / \mathrm{ha}$ & $35 \mathrm{~kg} / \mathrm{ha}$ & $48 \mathrm{~kg} / \mathrm{ha}$ & $58 \mathrm{~kg} / \mathrm{ha}$ \\
\hline Date of sowing & $\begin{array}{l}\text { 3rd April 2012, } \\
\text { 20th April } 2013\end{array}$ & $\begin{array}{l}\text { 3rd April 2012, } \\
\text { 20th April } 2013\end{array}$ & $\begin{array}{l}\text { 19th April 2012, } \\
\text { 2nd May } 2013\end{array}$ & $\begin{array}{l}\text { 19th April 2012, } \\
\text { 2nd May } 2013\end{array}$ \\
\hline Seed rate & $100 \mathrm{~kg} / \mathrm{ha}$ & $100 \mathrm{~kg} / \mathrm{ha}$ & $100 \mathrm{~kg} / \mathrm{ha}$ & $100 \mathrm{~kg} / \mathrm{ha}$ \\
\hline Harvest & $\begin{array}{l}\text { 1st August 2012, } \\
\text { 13th August } 2013\end{array}$ & $\begin{array}{l}\text { 1st August 2012, } \\
\text { 13th August } 2013\end{array}$ & $\begin{array}{l}\text { 24th July 2012, } \\
\text { 23rd August } 2013\end{array}$ & $\begin{array}{l}\text { 24th July 2012, } \\
\text { 23rd August } 2013\end{array}$ \\
\hline
\end{tabular}

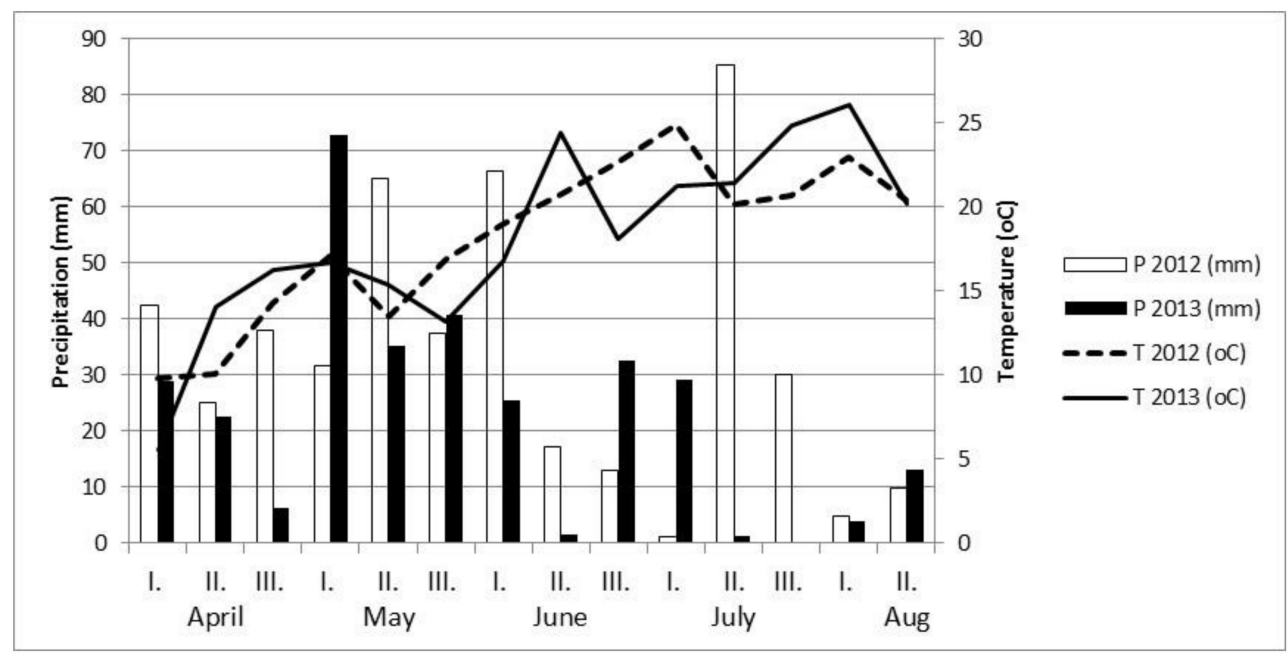

Figure 1. Rainfall (sum) and mean ten-day temperatures in the years 2012 and 2013 in the Savinja Valley region. 


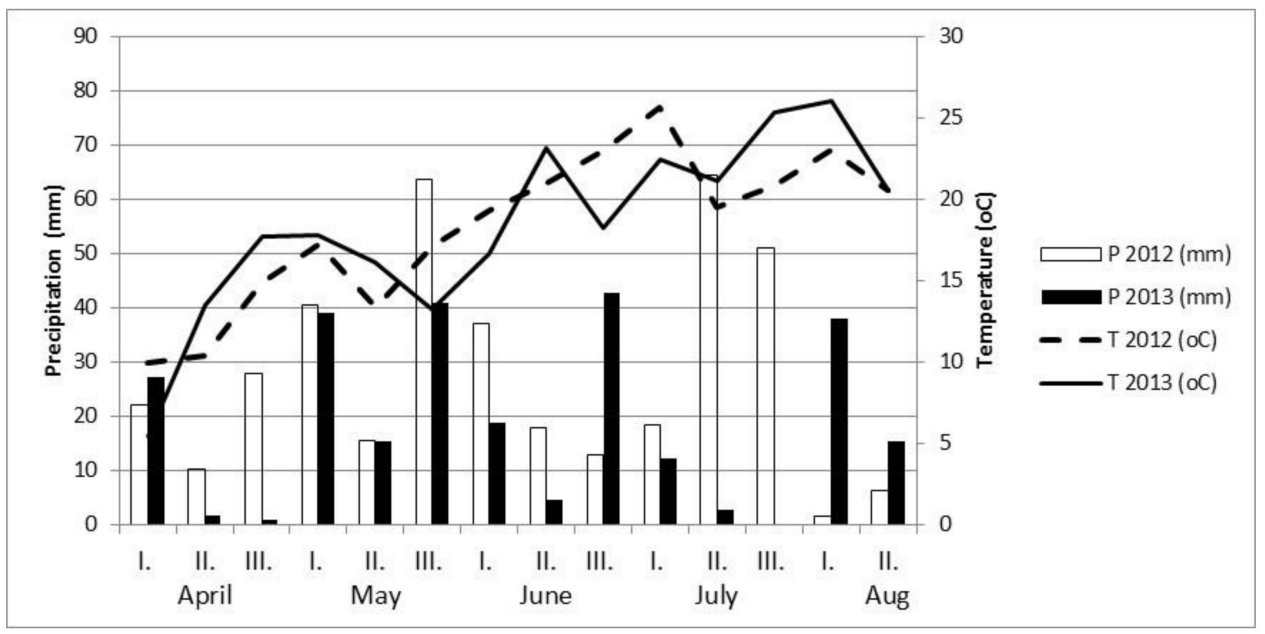

Figure 2. Rainfall (sum) and mean ten-day temperatures in the years 2012 and 2013 in the East Slovenia region.

In both investigated years, hot and dry weather prevailed during the seed ripening. In July 2012, there was heavy hail in the Savinja Valley, while East Slovenia experienced heavy hail, strong winds and rainfall, which negatively affected the growth and development of crops.

\subsection{Experimental Design and Treatments}

Varietal field trials were conducted as block field trials replicated four times. The size of each plot was $36 \mathrm{~m}^{2}(6 \mathrm{~m} \times 6 \mathrm{~m})$.

Six linseed varieties, which originated in France and are described as early varieties, with good seed yield and content of oil, were investigated: Recital, Niagara, Princess, Altess, Comtess and Duchess. According to the declaration of varieties (2018), Niagara and Princess contain the most oil (48\%), with Princess being rich in omega-3 FA content (60\%) and well-suited to southern areas, having stable yield under drought stress conditions. For Altess and Comtess, their high yields are emphasized, while the Comtess variety is also rich in oil and omega-3 content. The Duchess variety has higher productivity than Niagara [19].

\subsection{Plot Establishment and Management}

For the subsequent sowing, the soil was well prepared in autumn. Seeding was done using an experimental plot seeder (Wintersteiger Plotseed TC, Ried im Innkreis, Upper Austria) at a rate of $100 \mathrm{~kg} / \mathrm{ha}$ in spring. In 2013, due to the constant rainfall resulting in wet and cold ground, the soil could not be prepared until mid-April, so the sowing was carried out later than in 2012. The sowing times are presented in Table 1. No irrigation was included. Basagran $480(1.8 \mathrm{~L} / \mathrm{ha})$-a selective contact herbicide intended to eliminate annual and some perennial broadleaf weeds-was used after the weeds' emergence. No other phytopharmaceutical products were used. Nitrogen $(\mathrm{N})$ was added in two equally sized amounts ( $30 \mathrm{~kg} / \mathrm{ha} \mathrm{N}$ ) in the form of KAN fertilizer (after the sowing and at the start of blossoming). Before the second N fertilization and after the harvest in 2013, the Nmin (nitrate and ammonium form of $\mathrm{N}$ ) content of the soil was measured (Table 1). Harvesting was carried out, plot-by-plot, using a plot-harvester at the technical maturity of the crops: the timing is presented in Table 1.

\subsection{Data Collection and Computation}

Yield per plot was weighed immediately after harvest, and samples per plot for moisture content (Analytica EBC 7.2, 1998) and oil content (Soxhlet method; SIST EN ISO 659:1998) were taken promptly. The seeds were ground in a grinder to a granulation below $2 \mathrm{~mm}$. $10 \mathrm{~g}$ of the ground sample 
was transferred to a flask fitted with a Soxhlet apparatus. We added $150 \mathrm{~mL}$ of hexane solvent (Sigma-Aldrich, St. Louis, MO, USA). The extraction was performed for $6 \mathrm{~h}$. The solvent was removed from the sample by drying at $105-107^{\circ} \mathrm{C}$ to the constant weight. The oil content was calculated from the mass difference. All determinations were made in two replicates. Yields of seed dry matter and oil per plot/treatment were calculated.

Seed samples of average weight $(8 \mathrm{~kg})$, selected by variety (treatment) at the location PM2 (East Slovenia, light soil) in both experimental years, were pressed with an experimental screw mill. Compression was performed in two stages: the press cake, after the first compression, was fed into the screw mill again, followed by further compression. In the first stage, the rotational speed of the mill's screw was 19 turns/min; at the second stage, it was 13.5 turns/min. The quality and quantitative composition of essential and non-essential fatty acids after their derivatization into methyl esters were determined by gas chromatography (according to the method SIST EN ISO 12966: 2015).

\subsection{Statistical Analysis}

The results for seed yield, oil content and oil yield were processed by multifactor ANOVA using Statgraphics Centurion XV (Statgraphics Technologies Inc., The Plains, VA, USA) statistical software. Main effects and two-way interactions were determined. Three-way interactions were pooled into the residual (error) term in order to compute statistics (F-ratio, $p$-value). Differences between treatments were interpreted by Duncan's multiple range test $(p=0.05)$. Statistical results are provided in the Results and Discussion section and as Supplementary Materials (Tables S1, S2 and S3).

\section{Results and Discussion}

\subsection{Seed Yield}

The seed yield was significantly affected by the year of production, the production location and the variety (Tables 2 and 3). Weather conditions were more favorable in 2012 compared to 2013; the difference in average seed yield was $413 \mathrm{~kg} / \mathrm{ha}$ in favor of 2012. In 2013, the soil was wet and cold for a long time in the spring, causing the growth and development of linseed at the beginning of the growing season to be poor and the crop infrequent. In addition, there was a prolonged lack of precipitation in the summer of 2013, accompanied by high temperatures. Similarly, in the experiments by Casa et al. [20] in Italy, linseed seed yields varied greatly in response to weather and soil type: the environmental factors most likely to affect yield were high temperature and water shortage. By contrast, as reported by Angelini et al. [15] for field experiments during 2011-2014 in two regions of Italy, seed and oil yields were stable, irrespective of yearly differences in weather conditions. The reasons for diverse conclusions may vary, but one of the crucial factors may be the studied variety, which was not included in our investigation (variety Sideral).

The effect of the variety on the seed yield depended to some degree on the location (Table 3: F-ratio $=7.22 ; p<0.05)$ (Figure 3$)$, but not on the year (F-ratio $=1.54 ; p>0.05)$. In addition to the statistically significant effects of the factors year (F-ratio $=360 ; p<0.05)$ and location $(\mathrm{F}-$ ratio $=290$; $p<0.05$ ), their interaction (Figure 4) was also quite strong (F-ratio $=169 ; p<0.05$ ), which can mainly be attributed to much poorer linseed production in both the Savinja Valley locations in 2013 compared to 2012. Changing weather conditions apparently had a considerably lower detrimental impact on the yield in the East Slovenia locations. 
Table 2. Linseed seed yield, oil content in seed and oil yield with regard to variety, location and year of production $(2012,2013)$.

\begin{tabular}{lllll}
\hline & & $\begin{array}{c}\text { Seed Yield (kg } \\
\text { Dry Matter/ha) }\end{array}$ & $\begin{array}{c}\text { Oil Content (\% of } \\
\text { Dry Matter) }\end{array}$ & $\begin{array}{c}\text { Oil Yield } \\
\text { (kg/ha) }\end{array}$ \\
\hline \multirow{2}{*}{ Variety } & Recital (S1) & $1350 \mathrm{bc}$ & $37.7 \mathrm{a}$ & $509 \mathrm{~b}$ \\
& Niagara (S2) & $1324 \mathrm{c}$ & $39.2 \mathrm{a}$ & $515 \mathrm{~b}$ \\
& Princess (S3) & $1305 \mathrm{c}$ & $38.7 \mathrm{a}$ & $505 \mathrm{~b}$ \\
& Altess (S4) & $1461 \mathrm{a}$ & $37.1 \mathrm{a}$ & $527 \mathrm{~b}$ \\
& Comtess (S5) & $1482 \mathrm{a}$ & $38.4 \mathrm{a}$ & $566 \mathrm{a}$ \\
& Duchess (S6) & $1406 \mathrm{ab}$ & $37.4 \mathrm{a}$ & $523 \mathrm{~b}$ \\
\hline \multirow{2}{*}{ Location } & Savinja Valley-heavy soil, pH =6.8 (SV2) & $1379 \mathrm{~b}$ & $37.8 \mathrm{ab}$ & $685 \mathrm{a}$ \\
& Savinja Valley-medium-heavy soil, & $1907 \mathrm{a}$ & $36.6 \mathrm{~b}$ & $528 \mathrm{~b}$ \\
& pH = 6.6 (SV1) & $39.2 \mathrm{a}$ & $478 \mathrm{c}$ \\
& East Slovenia-heavy soil, pH =5.6 (PM1) & $1213 \mathrm{c}$ & $38.6 \mathrm{a}$ & $405 \mathrm{~d}$ \\
\hline \multirow{2}{*}{ Year } & East Slovenia-light soil, pH = 6.2 (PM2) & $1052 \mathrm{~d}$ & $34.8 \mathrm{~b}$ & $559 \mathrm{a}$ \\
& 2012 & $1594 \mathrm{a}$ & $41.3 \mathrm{a}$ & $489 \mathrm{~b}$ \\
\hline
\end{tabular}

* The same letter in the column for a particular factor indicates that there is no significant difference between the factor level means (Duncan's multiple range test, $p=0.05$ ).

Table 3. ANOVA table for the seed yield, oil content and oil yield.

\begin{tabular}{|c|c|c|c|c|c|}
\hline SEED YIELD & Sum of Squares & $D f$ & Mean Square & F-Ratio & P-Value \\
\hline \multicolumn{6}{|l|}{ MAIN EFFECTS } \\
\hline A:Variety & 860,618 & 5 & 172,124 & 7.56 & 0.0000 \\
\hline B:Block & 399,415 & 3 & 133,138 & 5.85 & 0.0008 \\
\hline C:Location & $19,805,300$ & 3 & $6,601,760$ & 290.14 & 0.0000 \\
\hline D:Year & $8,191,570$ & 1 & $8,191,570$ & 360.01 & 0.0000 \\
\hline \multicolumn{6}{|l|}{ INTERACTIONS } \\
\hline$A C$ & $2,463,350$ & 15 & 164,223 & 7.22 & 0.0000 \\
\hline$A D$ & 174,963 & 5 & $34,992.6$ & 1.54 & 0.1811 \\
\hline$C D$ & $11,560,600$ & 3 & $3,853,520$ & 169.36 & 0.0000 \\
\hline RESIDUAL & $3,549,570$ & 156 & $22,753.7$ & & \\
\hline TOTAL (CORRECTED) & $47,005,300$ & 191 & & & \\
\hline \multicolumn{6}{|l|}{ OIL CONTENT } \\
\hline \multicolumn{6}{|l|}{ MAIN EFFECTS } \\
\hline A: Variety & 26.6985 & 5 & 5.33971 & 1.33 & 0.3030 \\
\hline B: Location & 44.4273 & 3 & 14.8091 & 3.70 & 0.0357 \\
\hline C: Year & 503.755 & 1 & 503.755 & 125.84 & 0.0000 \\
\hline \multicolumn{6}{|l|}{ INTERACTIONS } \\
\hline$A B$ & 79.469 & 15 & 5.29793 & 1.32 & 0.2971 \\
\hline$A C$ & 11.7885 & 5 & 2.35771 & 0.59 & 0.7086 \\
\hline$B C$ & 143.902 & 3 & 47.9674 & 11.98 & 0.0003 \\
\hline RESIDUAL & 60.049 & 15 & 4.00326 & & \\
\hline TOTAL (CORRECTED) & 870.09 & 47 & & & \\
\hline \multicolumn{6}{|l|}{ OIL YIELD } \\
\hline \multicolumn{6}{|l|}{ MAIN EFFECTS } \\
\hline A: Variety & $19,543.7$ & 5 & $3,908.73$ & 4.36 & 0.0119 \\
\hline B: Location & 507,398 & 3 & 169,133 & 188.67 & 0.0000 \\
\hline C: Year & $58,940.1$ & 1 & $58,940.1$ & 65.75 & 0.0000 \\
\hline \multicolumn{6}{|l|}{ INTERACTIONS } \\
\hline$A B$ & 133,044 & 15 & $8,869.63$ & 9.89 & 0.0000 \\
\hline$A C$ & $4,148.67$ & 5 & 829.733 & 0.93 & 0.4915 \\
\hline$B C$ & 682,685 & 3 & 227,562 & 253.85 & 0.0000 \\
\hline RESIDUAL & $13,446.5$ & 15 & 896.433 & & \\
\hline TOTAL (CORRECTED) & $1,419,210$ & 47 & & & \\
\hline
\end{tabular}




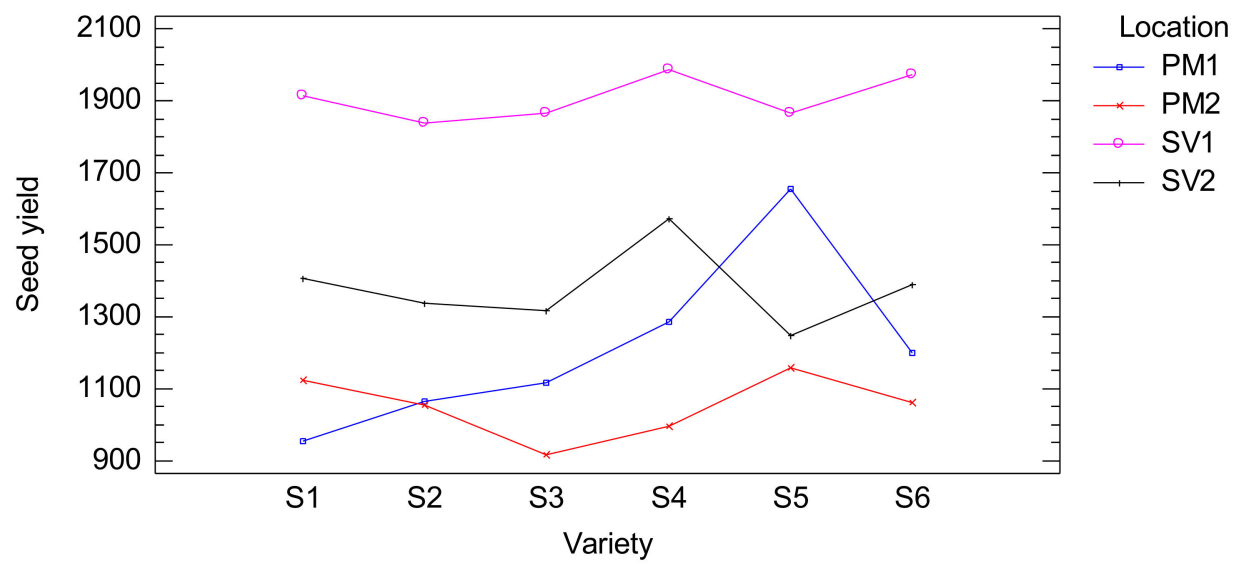

Figure 3. Interactions between linseed variety and location for seed yield ( $\mathrm{S} 1=$ variety Recital, S2 = variety Niagara, S3 = variety Princess, S4 = variety Altess, S5 = variety Comtess, S6 = variety Duchess).

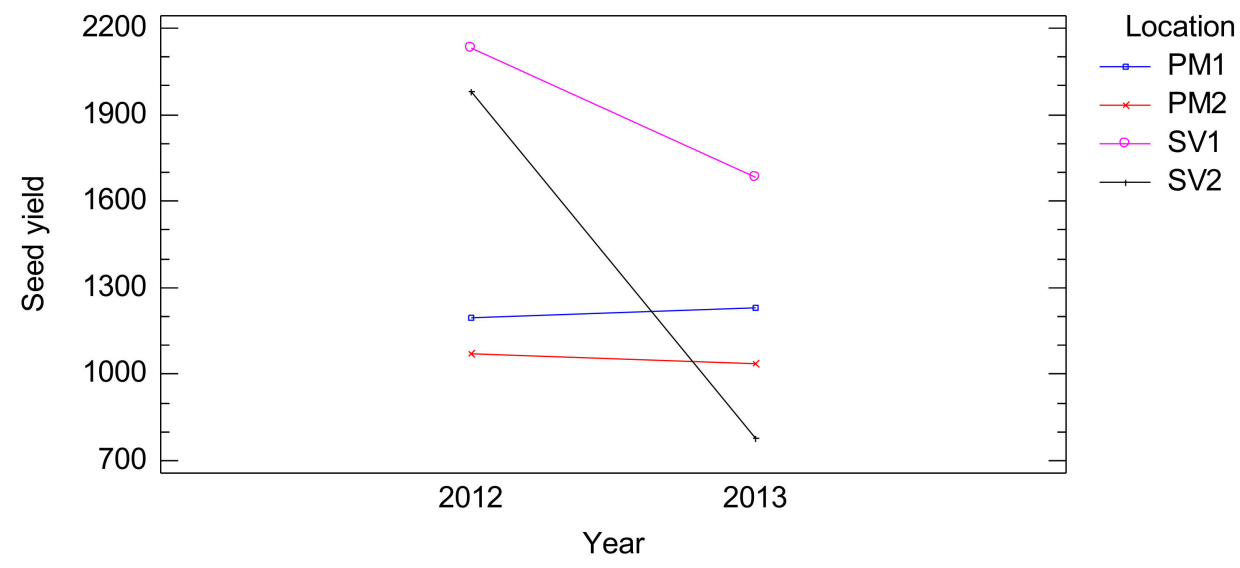

Figure 4. Interactions between production year and location for seed yield.

Achieved seed yields were above average according to global data on linseed seed yields, ranging from 120 in Iran to $2450 \mathrm{~kg} / \mathrm{ha}$ in Switzerland in 2018, with an average of approximately $1000 \mathrm{~kg} / \mathrm{ha}$ [3]. In favorable years, intensive cultivation can yield up to $4000 \mathrm{~kg} / \mathrm{ha}$.

Linseed varieties for oil production have a low need for water supply (a transpiration coefficient between 300 and 400). To achieve higher yields, a minimum of $120 \mathrm{~mm}$ of water is required in May and June. At all locations, this parameter was achieved or even exceeded: in 2012, the total precipitation in May and June in the Savinja Valley was $231 \mathrm{~mm}$, and in 2013, $208 \mathrm{~mm}$, while in East Slovenia, it was $187 \mathrm{~mm}$ in 2012 and $161 \mathrm{~mm}$ in 2013. However, Jacobsz and van der Merve [4] reported that, under rainfed conditions, linseed requires $450-750 \mathrm{~mm}$ of rain, spread evenly through the growing season. The Savinja Valley was found to be more favorable for linseed seed production compared to the East Slovenia region (lower precipitation amounts) in the investigated years: both locations in this geographical region achieved significantly higher yields (an average of $1643 \mathrm{~kg} / \mathrm{ha}$ in the Savinja Valley compared to $1133 \mathrm{~kg} / \mathrm{ha}$ in East Slovenia; Table 2). In East Slovenia, a higher seed yield was obtained at the location with heavy soil (with higher water holding capacity) compared to the location with light soil. Significantly higher seed yield was achieved on medium-heavy soil compared to heavy soil in the Savinja Valley (the region with higher precipitation amount).

Weather conditions and soil properties can have a great impact on the length of the linseed growing season [21]. The environmental factors most likely to affect yields are high temperatures and water shortages, which shortening the growing cycle. It was expressed in our experiments in a way that the 
linseed had a growing season from 96 days (East Slovenia) to 120 days (Savinja Valley) in the year 2012 and around 117 days at both locations in the year 2013. Zimmermann et al. [22] reported that linseed yield differed considerably between experimental locations in Spain and Germany: five different varieties grown in Spain produced only 39\% of seed yields compared to those grown in Germany.

The significantly highest seed yield average $(1907 \mathrm{~kg} / \mathrm{ha})$ was achieved on medium-heavy soil in the Savinja Valley, which was also, importantly, the location with the highest yield in both examined years. However, the yield in East Slovenia, on light soil, did not differ between the examined years $(1070 \mathrm{~kg} / \mathrm{ha}$ in $2012,1034 \mathrm{~kg} / \mathrm{ha}$ in 2013).

Heavy clays and dry, sandy soils are unsuitable for linseed production [4]. As depicted in Figure 4, the lowest seed yield was achieved in 2013 on heavy soil in the Savinja Valley (from 700 to $900 \mathrm{~kg} / \mathrm{ha}$ with regard to variety, the difference in yield across varieties being insignificant), in the year when the soil was wet and cold for a prolonged period in the spring. In East Slovenia, where there was less rain in the spring during that year, the seed yield was significantly higher at the location with heavy soil (1230 kg/ha) compared to the location with light soil (1034 kg/ha), for all investigated varieties.

The highest seed yields, on average, came from the Comtess and Altess varieties, followed by Duchess (Table 2). By year, the significantly highest yield in 2012 at both locations in the Savinja Valley was achieved from the Altess variety (2265 kg/ha and $2288 \mathrm{~kg} / \mathrm{ha}$, respectively). In East Slovenia, the significantly highest yield in 2012 gave at both locations Comtess variety $(1596 \mathrm{~kg} / \mathrm{ha}$ and 1239 $\mathrm{kg} / \mathrm{ha}$, respectively), followed by the Altess variety on heavy soil and the Recital variety on light soil. In 2013, at both locations in Savinja Valley, there were no significant differences in the yield between varieties, which gave, on average, $778 \mathrm{~kg} / \mathrm{ha}$ on heavy soil and $1683 \mathrm{~kg} / \mathrm{ha}$ on medium-heavy soil. In East Slovenia, the significantly highest yield at the location on heavy soil gave Comtess variety (yielded $1714 \mathrm{~kg} / \mathrm{ha}$ ) and on light soil Recital variety (1131 kg/ha), which yield did not differ significantly from the Comtess variety yield. The Comtess variety's high yield is also emphasized in its profile description [19].

Crop yield levels in both environments were in line with previous results obtained for different varieties in other countries. In the field experiments by Stafecka et al. [21], from 2010 to 2013 in Latvia, the Duchess variety produced an average seed yield of $1970 \mathrm{~kg} / \mathrm{ha}$ (the lowest yield being $1600 \mathrm{~kg} / \mathrm{ha}$ ), and adequate water supply was appreciated by this variety (2600 kg/ha in 2012). The Princess variety yielded from 1100 to $2200 \mathrm{~kg} / \mathrm{ha}$ according to the year, giving a $200 \mathrm{~kg} / \mathrm{ha}$ higher yield than the Duchess variety. The opposite was found in our locations.

\subsection{Oil Content and Oil Yield}

There were no significant differences between varieties regarding oil content (Table 3: $p>0.05$ ), but a significantly higher seed oil content was achieved in 2013 compared to 2012. In 2013, the crop was infrequent because of the wet and cold soil in spring; there was also a prolonged lack of precipitation in the summer, accompanied by high temperatures what followed by lower seed yield, but in contrary higher oil content. In addition, among the locations, the significantly lowest oil content was achieved in the Savinja Valley, on medium-heavy soil, where the seed yield was significantly the highest (Table 2), so we think there was a dilution effect. Considering years and locations separately, there were always Niagara and Princess varieties in the Savinja Valley with the highest oil content, followed by Recital variety.

Niagara was the variety with the highest average oil content (Table 2; 39.2\%), and this variety is described in its declaration to have a very high oil content [19]. However, in East Slovenia, the oil content differed according to variety and year. In 2013, a significantly lower oil content was achieved by Comtess and Duchess varieties on heavy soil (42.1\% and $42.3 \%$, respectively), but on light soil, these two varieties achieved significantly higher oil content $(44.6 \%$ and $46.4 \%$, respectively) compared to other varieties in the same year. However, Duchess variety produced the lowest oil content in East Slovenia on light soil in 2012. There were considerable differences in oil content for the East Slovenia locations between the examined years: in 2012, the content ranged between $30.0 \%$ and $38.9 \%$ according 
to the variety and location, while in 2013, it ranged between $42.1 \%$ and $46.4 \%$. Differences between years were not as great in the Savinja Valley locations. In the experiment by Smolova et al. [23] in the Czech Republic, the oil content of four different varieties, including the Recital variety (41.5\%), ranged from 38.9 to $42.5 \%$. In 2013, the oil content of seeds mostly exceeded $40 \%$, excluding the Savinja Valley location, on heavy soil. These results are comparable to those reported by Elayan Sohair et al. [16] and Andruszczak et al. [24] but are higher compared to Bayrak et al. [25] and Rasouli et al. [26]. In the field experiments conducted by Stafecka et al. [21] from 2010 to 2013 in Latvia, the Duchess variety had $44.9 \%$ oil content, and Princess had $49.1 \%$, while in our experiments, the oil content was lower for both varieties in both studied years.

The average oil yield and its content in seed dry mass vary greatly, depending on the source material (varieties, lines and population) $[16,24]$ and agronomical conditions, including the location of production, soil type, water supply, fertilization, sowing date and weather conditions [10,15,24-27]. The great variability of oil content, probably depending on the above-mentioned parameters, was evident in our experiments also: the oil yield of the studied linseed varieties, presented in Table 2, ranged from $292 \mathrm{~kg} / \mathrm{ha}$ to $828 \mathrm{~kg} / \mathrm{h}$ in the year 2012 and from $241 \mathrm{~kg} / \mathrm{ha}$ to $747 \mathrm{~kg} / \mathrm{ha}$ in the year 2013, with averages of $559 \mathrm{~kg} / \mathrm{ha}$ and $489 \mathrm{~kg} / \mathrm{ha}$, respectively. In East Slovenia, the oil yield of linseed in 2012 was lower than in 2013, but by contrast, in the Savinja Valley, the oil yields were higher in 2012, especially on heavy soil, while yields in 2013 were very low (on average $291 \mathrm{~kg} / \mathrm{ha}$ ). In both years, the highest oil yield was achieved in the Savinja Valley: 27\% higher than in the East Slovenia region. In Germany, oil yield was reported from $0.57 \mathrm{t} / \mathrm{h}$ a to $1.06 \mathrm{t} / \mathrm{ha}$ with regard to variety in conventional farming and in Switzerland from $0.49 \mathrm{t} / \mathrm{ha}$ to $0.67 \mathrm{t} / \mathrm{ha}$ in organic farming.

The highest oil yield was observed in both years for the Comtess, Altess and Duchess varieties, averaging $566 \mathrm{~kg} / \mathrm{ha}, 527 \mathrm{~kg} / \mathrm{ha}$ and $523 \mathrm{~kg} / \mathrm{ha}$, respectively. The general trend of oil yield was opposite to the trend of oil content in seeds in both years and could be attributed to the dilution effect.

Our results are in accordance with the findings of other studies. The linseed is sensitive to drought at the initial development stage, at flowering and during early seed development, indicating that seed yield and oil content can be maximized by maintaining soil moisture to adequate levels during the corresponding periods [28]. Water stress limits linseed growth by hastening physiological maturity, and consequently, the period of seed oil synthesis and deposition. As Anastasiu et al. [8] proposed, such data can be further used to estimate the oil production of a variety regarding a given meteorological annual forecast.

\subsection{Fatty Acid Composition of Cold Pressed Oil}

The fatty acids profiles for the studied varieties, produced in 2012 and 2013 (average sample from all experimental locations), are shown in Table 4. Linseed oil consists mainly of $\alpha$-linolenic, linoleic, oleic, palmitic and stearic acids. The main fatty acid is $\alpha$-linolenic, an omega- 3 tri-unsaturated fatty acid ranging from $47.36 \%$ (Recital) to $53.01 \%$ (Comtess) in the year 2012 and from $50.40 \%$ (Niagara) to 53.03 (Recital) in the year 2013. The commonly recognized high content of $\alpha$-linolenic acid is above $50 \%[15,24,29]$. In 2013, all the varieties in our study exceeded 50\%, while in 2012, the Recital and Niagara varieties fell below this level. From the point of view of the $\alpha$-linolenic acid content, Altess and Duchess cultivars are observed as high-leveled in both years (above the average for both studied years 2012 and 2013; 50.27\% and 51.61\%, respectively); at the opposite pole is Niagara, with modest $\alpha$-linolenic acid levels for both studied years (47.36\% and $50.40 \%$, respectively). In terms of the linoleic acid concentration (mean values 13.97\% and 14.74\%, respectively for 2012 and 2013), varieties Niagara and Comtess reached the content above average in both years. Recital differs from the other five varieties with respect to oleic acid content in 2012 (24.78\%, compared to the other five varieties ranging from 19.97 to $23.37 \%$ ), while in 2013 variety Niagara differs (23.09\%, compared to other five varieties ranging from $21.79 \%$ to $22.79 \%$ ). The main saturated fatty acids (palmitic and stearic) are found in amounts below average (6.05\% and 6.09\%, respectively for 2012 and 2013) for two varieties in 2012 and 
for four in 2013. Arachidic and gonodoic acids were detected in trace amounts (on average less than $0.5 \%)$. Overall, these results agree with other papers dealing with linseed oil composition [6,30].

Table 4. The content of some fatty acids in cold-pressed oils from different linseed varieties, produced in East Slovenia on light soil, in years 2012 (1st) and 2013 (2nd) (in \%).

\begin{tabular}{|c|c|c|c|c|c|c|c|c|c|c|c|c|c|c|c|c|}
\hline \multirow{2}{*}{$\begin{array}{c}\text { Variety } \\
\text { Year }\end{array}$} & \multicolumn{2}{|c|}{ C16:0* } & \multicolumn{2}{|c|}{ C18:0* } & \multicolumn{2}{|c|}{ C18:1 * } & \multicolumn{2}{|c|}{$\mathrm{C} 18: 2$ * } & \multicolumn{2}{|c|}{$\mathrm{C} 18: 3^{*}$} & \multicolumn{2}{|c|}{ C20:0* } & \multicolumn{2}{|c|}{$\mathrm{C} 20: 1^{*}$} & \multicolumn{2}{|c|}{$\omega 3: \omega 6$} \\
\hline & 1st & 2nd & 1st & 2nd & 1st & 2nd & 1st & 2nd & 1st & 2nd & 1st & 2nd & 1st & 2nd & 1st & 2nd \\
\hline Recital & 6.46 & 5.89 & 4.98 & 4.51 & 24.78 & 21.79 & 14.43 & 14.13 & 47.36 & 53.03 & 0.47 & 0.44 & 1.22 & 0.03 & $3.3: 1$ & $3.8: 1$ \\
\hline Niagara & 5.30 & 6.25 & 5.83 & 4.80 & 22.51 & 23.09 & 16.12 & 15.11 & 49.01 & 50.40 & 0.36 & 0.14 & 0.52 & 0.03 & $3.0: 1$ & $3.3: 1$ \\
\hline Princess & 6.55 & 6.19 & 5.53 & 4.67 & 22.98 & 22.79 & 12.82 & 15.02 & 50.76 & 50.98 & 0.45 & 0.17 & 0.64 & 0.03 & $4.0: 1$ & $3.4: 1$ \\
\hline Altess & 6.10 & 6.05 & 6.06 & 4.57 & 23.37 & 22.34 & 12.65 & 14.63 & 50.42 & 52.05 & 0.41 & 0.15 & 0.64 & 0.03 & $4.0: 1$ & $3.6: 1$ \\
\hline Comtess & 6.47 & 6.07 & 5.70 & 4.57 & 19.97 & 22.49 & 14.17 & 14.89 & 53.01 & 51.34 & 0.39 & 0.43 & 0.00 & 0.03 & $3.7: 1$ & $3.4: 1$ \\
\hline Duchess & 5.40 & 6.08 & 5.95 & 4.62 & 22.96 & 22.43 & 13.63 & 14.66 & 51.05 & 51.86 & 0.72 & 0.15 & 0.00 & 0.03 & $3.7: 1$ & $3.5: 1$ \\
\hline \multicolumn{5}{|c|}{ Lipid Number } & \multicolumn{6}{|c|}{ Common name } & \multicolumn{6}{|c|}{ Systematic Name } \\
\hline \multicolumn{5}{|c|}{$C_{16: 0}$} & \multicolumn{6}{|c|}{ Palmitic acid } & \multicolumn{6}{|c|}{ Hexadecanoic acid } \\
\hline \multicolumn{5}{|c|}{$\mathrm{C}_{18: 0}$} & \multicolumn{6}{|c|}{ Stearic acid } & \multicolumn{6}{|c|}{ Octadecanoic acid } \\
\hline \multicolumn{5}{|c|}{$\mathrm{C}_{18: 1}$} & \multicolumn{6}{|c|}{ Oleic acid } & \multicolumn{6}{|c|}{ cis-9-Octadecenoic acid } \\
\hline \multicolumn{5}{|c|}{$\mathrm{C}_{18: 2}$} & \multicolumn{6}{|c|}{ Linoleic acid } & \multicolumn{6}{|c|}{ cis, cis-9,12-Octadecadienoic acid } \\
\hline \multicolumn{5}{|c|}{$\mathrm{C}_{18: 3}$} & \multicolumn{6}{|c|}{$\alpha$-Linolenic acid } & \multicolumn{6}{|c|}{ cis, cis, cis-9,12,15-Octadecatrienoic acid } \\
\hline \multicolumn{5}{|c|}{$C_{20: 0}$} & \multicolumn{6}{|c|}{ Arachidic acid } & \multicolumn{6}{|c|}{ Eicosanoic acid } \\
\hline \multicolumn{5}{|c|}{$C_{20: 1}$} & \multicolumn{6}{|c|}{ Gonodoic acid } & \multicolumn{6}{|c|}{ cis-Eicos-11-enoic acid } \\
\hline
\end{tabular}

In addition, as it is evident from Table 4, the fatty acid profile of linseed oil varies not only depending on the variety but also on the year of production. The same variety (Recital) may produce in one year the highest amount of the most important component of linseed oil, an $\alpha$-linolenic acid, while in another year the lowest $(47.36 \%$ and $53.03 \%$, respectively for 2012 and 2013$)$, most probably related to specific weather conditions of studied years. In accordance with data obtained in other studies $[8,26]$, weather conditions (temperature and rainfall regime) may have an important effect not only on the oil production but also on linseed oil quality or fatty acid composition.

In comparison to other oilseed crops, linseed is the richest source of $n-3 \alpha$-linolenic acid, the omega- 3 fatty acid, which has been recognized as beneficial for human health, especially cardiovascular health [31,32]. In addition, the omega-3 and omega- 6 fatty acids in linseed oil have a favorable ratio for human health [33]. The content of $\alpha$-linolenic acid ranged from $47.4 \%$ to $53.0 \%$ (average $50.3 \%$ ) in 2012 and from 50.4\% to 53.0\% (average 51.6\%) in 2013 (Table 3), while the content of linoleic acid ranged from $12.7 \%$ to $16.1 \%$ (average $14.0 \%$ ), in 2012 and $14.1 \%$ to $15.1 \%$ (average $14.7 \%$ ) in 2013 . The omega-3:omega-6 ratio, presented in Table 3, ranged from 3.0-4.0:1 in 2012 and 3.2-3.81 in 2013. Observed ratios were in the range of 3:1 to 4:1, which is in accordance with other studies and has been recognized as favorable for human health [13,33-35].

\section{Conclusions}

Observed linseed varieties were monitored in Slovenia for two years (2012 and 2013) in a field trial at four locations in order to give a new viewpoint of cultivating linseed, to estimate the seed and oil production regarding weather conditions and locations with different soil characteristics. Results show that the seed yield was significantly affected by the year of production (lower in 2013 by $413 \mathrm{~kg} / \mathrm{ha}$ ), the production location and the variety. From the results of our study and in accordance with reviewed literature, it can be concluded that the environmental factors which most likely negatively affected the seed yield are high temperatures during summer with water shortages. In addition, also wet and cold soil in spring negatively affected the seed yield because of the negative impact on plant emergence.

The highest seed yield was reached at the location with mid-heavy soil in the region with higher precipitation amounts, and the lowest on light soils in the region with lower precipitation amounts. 
In regions with lower precipitation amounts, higher seed yield is expected on heavy soil compared to light soil, while in regions with higher precipitation amounts, medium-heavy soils prosper over heavy soils. From the perspective of investigated varieties, Comtess and Altess varieties, followed by Duchess, would be recommendable for Slovenian environmental conditions if we are looking for high seed yield. On the other hand, the Comtess variety also gave the significantly highest oil yield, while there were no significant differences in oil content between varieties. For light soil in the region with a lower precipitation amount, the Recital variety gave the best results besides the Comtess variety. Significantly the highest yield was got in 2012 at both locations in the Savinja Valley by the Altess variety ( $2265 \mathrm{~kg} / \mathrm{ha}$ and $2288 \mathrm{~kg} / \mathrm{ha}$, respectively).

When high seed yields are reached, a bit lower oil content can be expected because of the dilution effect. In accordance with our findings, the seed yield had a higher impact on oil yield compared to oil content, so the highest oil yields were reached with high seed yield.

In relation to the nutrition value of linseed oil, and its impacts on health, the fatty acid profile of linseed oil can vary significantly. In addition to genetic factors, environmental conditions also play an important role, especially weather conditions (temperature and rainfall regime). When the content of $\alpha$-linolenic acid, as one of the most important fatty acids from the health aspect, was highly related to genetic and environmental factors, on the other hand, the ratio of omega- 3 and omega- 6 fatty acids were recognized as favorable for human health for all studied varieties. In the Slovenian experiment, Altess and Duchess varieties were observed as high-leveled in both years; at the opposite pole is Niagara, with modest $\alpha$-linolenic acid levels for both studied years.

Since it is reported in the literature, cool climatic conditions in temperate regions lead to a high share of omega- 3 fatty acids, especially the most important $\alpha$-linolenic acid, furthermore detailed studies are needed to examine the impact of specific climate conditions on the production of compounds beneficial for human health.

Supplementary Materials: The following are available online at http://www.mdpi.com/2073-4395/10/11/1770/s1, Table S1: Least-squares means table for the seed yield with 95\% confidence intervals. Table S2: Least-squares means table for the oil content with $95 \%$ confidence intervals. Table S3: Least-squares means table for the oil yield with $95 \%$ confidence intervals.

Author Contributions: The paper was prepared by all listed authors. All authors have read and agreed to the published version of the manuscript. Conceptualization, B.Č. and A.K.; Data curation, B.Č.; Formal analysis, A.H.; Investigation, B.Č. and S.̌̌.; Methodology, B.Č.; Writing—original draft, A.K.; Writing—review \& editing, B.Č.

Funding: This work was supported by the Ministry of Agriculture, Forestry and Food of the Republic of Slovenia and the Slovenian Research Agency, with research project reference V4-1138 and programs reference P4-0121 (Biochemical and biophysical characterization of natural compounds) and P3-0395 (Nutrition and Public health), funded by the Slovenian Research Agency.

Conflicts of Interest: The authors declare no conflict of interest.

\section{References}

1. Zanetti, F.; Monti, A.; Berti, M.T. Challenges and Opportunities for New Industrial Oilseed Crops in EU-27: A Review. Ind. Crop Prod. 2013, 50, 580-595. [CrossRef]

2. Klein, J.; Zikeli, S.; Claupein, W.; Gruber, S. Linseed (Linum Usitatissimum) as an Oil Crop in Organic Farming: Abiotic Impacts on Seed Ingredients and Yield. Org. Agric. 2016, 7, 1-19. [CrossRef]

3. FAOSTAT. Available online: http://www.fao.org/faostat/en/\#data (accessed on 22 October 2020).

4. Jacobsz, M.J.; van der Merwe, W.J.C. Production Guidelines for Flax. 2012. Available online: http: //www.nda.agric.za/docs/Brochures/ProGuiFlax.pdf (accessed on 22 June 2020).

5. Worku, N.; Heslop-Harrison, J.S.; Adugna, W. Diversity in 198 Ethiopian Linseed (Linum Usitatissimum) Accessions Based on Morphological Characterization and Seed Oil Characteristics. Genet. Res. Crop Evol. 2015, 62, 1037-1053. [CrossRef]

6. Bernacchia, R.; Preti, R.; Vinci, G. Chemical Composition and Health Benefits of Flaxseed. Austin J. Nutri. Food Sci. 2014, 2, 1045. 
7. Wilcox, J.R.; Shibles, R.M. Interrelationships Among Seed Quality Attributes in Soybean. Crop Sci. 2001, 41, 11-14. [CrossRef]

8. Anastasiua, A.E.; Chira, N.A.; Banub, I.; Ionescuc, N.; Stana, R.; Roscaaa, S.I. Oil Productivity of Seven Romanian Linseed Varieties as Affected by Weather Conditions. Ind. Crops Prod. 2016, 86, 219-230. [CrossRef]

9. Franklin, P.; Gardner, R.; Pearce, B.; Mitchell, R.L. Physiology of Crop Plants; Scientific Press: Christchurch, New Zealand, 2010; p. 336.

10. Zając, T.; Oleksy, A.; Klimek-Kopyra, A.; Kulig, B. Biological Determinants of Plant and Crop Productivity of Flax (Linum Usitatissimum L.). Acta Agrobot. 2012, 65, 3-14. [CrossRef]

11. Alonso, D.L.; Maroto, F.G. Plants as 'Chemical Factories' for the Production of Polyunsaturated Fatty Acids. Biotechnol. Adv. 2000, 18, 481-497. [CrossRef]

12. Oomah, B. Flaxseed as a Functional Food Source. J. Sci. Food Agric. 2001, 81, 889-894. [CrossRef]

13. Simopoulos, A.P. The Omega-6/Omega-3 Fatty Acid Ratio: Health Implications. Oilseeds Fats Crops Lipids 2010, 17, 267-275. [CrossRef]

14. Simoupolos, A.P. Omega-3 Fatty Acids in Health and Disease and in Growth and Development. Am. J. Clin. Nutr. 1990, 11, 296-302. [CrossRef] [PubMed]

15. Angelini, L.G.; Tavarini, S.; Antichi, D.; Foschi, L.; Mazzoncini, M. On-Farm Evaluation of Seed Yield and Oil Quality of Linseed (Linum Usitatissimum L.) in Inland Areas of Tuscany, Central Italy. Ital. J. Agron. 2016, 11. [CrossRef]

16. Elayan Sohair, E.D.; Abdallah Amany, M.; Naguib, A.; Mahmoud Doaa, I. Effect of Sowing Date on Yield, Fiber and Seed Quality of Eight Flax Genotypes. American-Eurasian. J. Agric. Environ. Sci. 2015, 15, 886-895.

17. Dabalo, D.Y.; Singh, C.S.; Weyessa, B. Genetic Variability and Association of Characters in Linseed (Linum Usitatissimum L.) Plant Grown in Central Ethiopia Region. Saudi J. Biol. Sci. 2020, 27, 2192-2206. [CrossRef] [PubMed]

18. ARRS: Agrometeorological Portal of the Republic of Slovenia, (October 2012 and October 2013). Available online: http://agromet.mkgp.gov.si/APP/Home/METEO/-1 (accessed on 22 June 2020).

19. Oleolin. L'union de Competences pour la Reussite de Votre Lin. Lin Oleagineux de Printemps. (The Union of Skills for the Success of Your Flax. Spring Oilseed Flax). Available online: http://www.linea.sitew.com/fs/ Root/9gqsj-presentation_varietes_LOP_2011.pdf (accessed on 22 June 2020).

20. Casa, R.; Russell, G.; Lo Cascio, B.; Rossini, F. Environmental Effects on Linseed (Linum Usitatissimum L.) Yield and Growth of Linseed at Different Stand Densities. Eur. J. Agron. 1999, 11, 267-278. [CrossRef]

21. Stafecka, I.; Stramkale, V.; Grauda, D. Yield Development of Flax Varieties and Lines within Variable Environment in Latvia. In Proceedings of the 10th International Scientific and Practical Conference: Environment, Technology, Resources, Volume II, Rezekne, Latvia, 18-20 June 2015; pp. 297-302.

22. Zimmermann, R.; Bauermann, U.; Moralesm, F. Effects of Growing Site and Nitrogen Fertilization on Biomass Production and Lignan Content of Linseed (Linum Usitatissimum L.). J. Sci. Food Agric. 2006, 86, 415-419. [CrossRef]

23. Smolova, J.; Nemečkova, I.; Klimešova, M.; Švandrlik, Z.; Bjelkova, M.; Filip, V.; Kyselka, J. Flaxseed Varieties: Composition and Influence on the Growth of Probiotic Microorganisms in Milk. Czech J. Food Sci. 2017, 35, $18-23$.

24. Andruszczak, S.; Gawlik-Dziki, U.; Kraska, P.; Kwiecińska-Poppe, E.; Różyło, K.; Pałys, E. Yield and Quality Traits of Two Linseed (Linum Usitatissimum L.) Varieties as Affected by Some Agronomic Factors. Plant. Soil Environ. 2015, 61, 247-252. [CrossRef]

25. Bayrak, A.; Kiralan, M.; Ipek, A.; Arslan, N.; Cosge, B.; Khawar, K.M. Fatty Acid Compositions of Linseed (Linum Usitatissimum L.) Genotypes of Different Origin Cultivated in Turkey. Biotechnol. Biotechnol. Equip. 2010, 24, 1836-1842. [CrossRef]

26. Rasouli, M.; Akbari, T.; Fattahi, M.; Fattahi, B. Interaction between Various Irrigation and Nitrogen Levels Affect on Linseed (Linum Utitatissimum L.) Fatty Acids, Yield and Growth Factors. Anal. Chem. Lett. 2011, 1, 254-260. [CrossRef]

27. Klimek-Kopyra, A.; Zajac, T.; Micek, P.; Borowiec, F. Effect of Mineral Fertilization and Sowing Rate on Chemical Composition of Two Linseed Varietys. J. Agric. Sci. 2013, 5, $224-229$.

28. Gabiana, C.; McKenzie, B.A.; Hill, G.D. The Influence of Plant Population, Nitrogen and Irrigation on Yield and Yield Components of Linseed. Agron. N. Z. 2005, 35, 44-56. 
29. Silska, G. Genetic Resources of Flax (Linum Usitatissimum L.) as Very rich Sources of $\alpha$-Linolenic Acid. Herba Pol. 2017, 63, 26-33. [CrossRef]

30. Bloedon, L.T.; Szapary, P.O. Flaxseed and Cardiovascular Risk. Nutr. Rev. 2004, 62, 18-27. [CrossRef]

31. Parikh, M.; Netticadan, T.; Pierce, G.N. Flaxseed: Its Bioactive Components and Their Cardiovascular Benefits. Am. J. Physiol. Heart Circ. Physiol. 2018, 314, H146-H159. [CrossRef]

32. Saini, R.K.; Keum, J.S. Omega-3 and Omega-6 Polyunsaturated Fatty Acids: Dietary Sources, Metabolism, and Significance-A Review. Life Sci. 2018, 203, 255-267. [CrossRef]

33. EFSA. Labelling Reference Intake Values for N-3 and N-6 Polyunsaturated Fatty Acids: Scientific Opinion. EFSA J. 2009, 1176, 1-11.

34. Mueller, K.; Eisner, P.; Yoshie-Stark, Y.; Nakada, R.; Kirchhoff, E. Functional Properties and Chemical Composition of Fractionated Brown and Yellow Linseed Meal (Linum Usitatissimum L.). J. Food Eng. 2010, 98, 453-460. [CrossRef]

35. Simopoulos, A.P. Omega-6/Omega-3 Essential Fatty Acid Ratio and Chronic Diseases. Food Rev. Int. 2004, 20, 77-90. [CrossRef]

Publisher's Note: MDPI stays neutral with regard to jurisdictional claims in published maps and institutional affiliations.

(C) 2020 by the authors. Licensee MDPI, Basel, Switzerland. This article is an open access article distributed under the terms and conditions of the Creative Commons Attribution (CC BY) license (http://creativecommons.org/licenses/by/4.0/). 